
3 Research Square
Preprints are preliminary reports that have not undergone peer review.
They should not be considered conclusive, used to inform clinical practice, or referenced by the media as validated information.

\title{
The Effect of Long-Haul COVID Towards Domains of The Health Related Quality of Life Among Recovered Hospitalized Patients
}

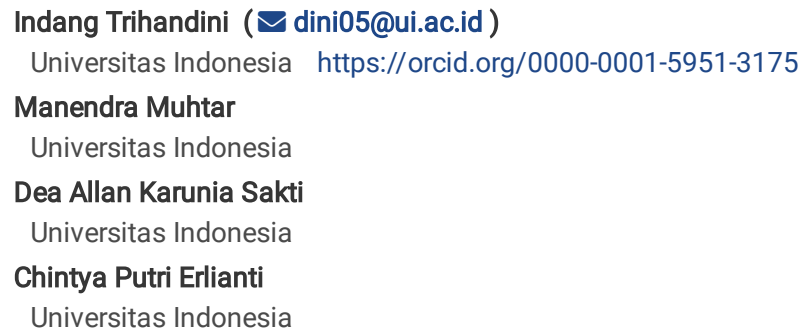

\section{Research}

Keywords: Long-Haul COVID, WHOQOL-BREF Domains, Health-Related Quality of Life (HRQOL)

Posted Date: February 7th, 2022

DOI: https://doi.org/10.21203/rs.3.rs-1300078/v1

License: () (1) This work is licensed under a Creative Commons Attribution 4.0 International License. Read Full License 


\section{Abstract \\ Background}

People with long-haul COVID could experience various health problems, from mild to more severe ones. This research aimed to identify the effect of long-haul COVID, specifically on the Quality of Life domains, experienced by COVID 19 survivor. Data collection was carried out online, using data from DKI Jakarta hospitalized patients who have been confirmed with and recovered from SARS-CoV-2 infections. We selected patients who have a minimum of 28 days after being hospitalized for COVID 19 positive. Logistic regression technique was used to analyze the data. The questionnaire used in this research was measured by WHOQOL-BREF. The WHOQOL-BREF is a self-administered questionnaire comprising 26 questions on the individual's perceptions of their health and wellbeing over the previous two weeks. Prior to the data collection, we tested the questionnaire with 30 recovered patients who were hospitalized outside DKI Jakarta.

\section{Result}

In total of 172 recovered inpatients who filled out the questionnaire correctly and aged 18 years and above, were selected by random sampling. Almost onethird (30.2\%) of the recovered inpatients had long-haul COVID, with $23.8 \%$ experiencing one long-haul symptom and $6.4 \%$ experiencing more than one symptom. This research also showed that the long-haul effects of COVID affected almost all domains of Quality of Life except the environmental one. Age, gender, and marital status were covariates for the association between long-haul COVID and The Quality of Life.

\section{Conclusion}

Due to the long-haul COVID effect on the decline in Quality of Life, the continuation of health services after discharge from the hospital is an important program to prevent it.

\section{Introduction}

Long-Haul COVID, also known as post-COVID syndrome, post-acute sequelae of COVID 19 (PASC), or chronic COVID 19 syndrome (CCS), is a condition characterized by long-haul term sequelae appearing or persisting after the typical convalescence period of COVID-19.[1] Long-haul COVID can affect nearly every organ system with a wide range of symptoms are commonly discussed, including fatigue, headaches, shortness of breath, anosmia, parosmia, muscle weakness, low fever and cognitive dysfunction. sequelae, nervous system and neurocognitive disorders, mental health disorders, metabolic disorders, cardiovascular disorders, gastrointestinal disorders, malaise, fatigue, musculoskeletal pain, and anemia. [2][3][4][5]

The long-haul COVID tends to occur more frequently in survivors who have more severe symptoms during infection.[7] The effectiveness of treatment measures to treat this condition is still being sought. These conditions can be associated with health-related quality of life have become an important issue in medical and psychological research. WHO defines quality of life as individuals' perceptions of their position in life in the context of the culture and value systems in which they live, as well as in relation to their goals, expectations, standards, and concerns.[8] WHO has assessed the quality of life through the WHOQOL-100 questionnaire which is a multidimensional evaluation of individuals' perceptions of their health status, psychosocial status, and other aspects of their lives. [9] Subsequently, WHO created a simplified version of WHOQOL-100 called the WHOQOL-BREF.(10) The WHOQOL-BREF questionnaire can be completed independently by the respondent or with the assistance of a trained interviewer.[8][10]

WHOQOL-BREF demonstrated good discriminant validity, content validity, internal consistency, and retest reliability, and was highly correlated with WHOQOL100 domain scores. [10], [11][12] The Indonesian version of the WHOQOL-BREF instrument showed a near-perfect match of the two general items and good agreement of the four domains. Therefore it can be concluded that the WHOQOL-BREF is a consistent and stable instrument to measure the quality of life of Indonesian people in general. [13] [14][15].

Therefore, further in-depth studies are needed to examine the health problems in COVID 19 patients who have been declared cured after being discharged from the hospital. Thus, this research has aimed to identify the effect of Long-Haul COVID symptoms on the Quality of Life of Recovered Patients in Hospitals in Jakarta. It is expected that the results of this research could be used to strengthen post-hospitalization supervision for recovered patients.

\section{Research Method}

The research related to the long-haul COVID had passed an ethical permit and data collection permit from the DKI Health Office for 6 months. The research was conducted in DKI Jakarta, the capital of Indonesia and the center of the COVID 19 spread in Indonesia. Due to conditions that did not allow for the data to be collected directly, data collection was conducted online using a database from reports of COVID 19 patients from various hospitals and health centers. The respondents were randomly selected from a list of COVID 19 patients who had recovered. This list was provided by the Provincial Health Office of DKI Jakarta. Several difficulties, such as a slow pace of data collection, as some patients who had recovered from COVID 19 refused to fill out online surveys, were encountered during the implementation. Eventually, only 281 respondents were obtained. The database of COVID 19 patient reports from various hospitals and health centers were also not well organized and some of the data reported were incomplete. After data cleaning and making sure that the respondents met the inclusion criteria (aged 18 or more, were hospitalized patients, and interviewed a minimum of 28 days after hospitalized COVID 19 positive) and properly filled out the form, the total number of respondents was 172. 
There are many terms to describe the symptoms of The Long-Haul COVID and how to assess them too. Long-Haul COVID, as the main independent variable in this study, followed the term with a history of confirmed SARS-CoV-2 infection, at an interview at least 28 days after completion of hospitalization for COVID 19 positive patients with symptoms who did not have the experience before becoming sick. Other independent variables, including gender, age, length of treatment, length from onset to interview, marital status, occupation, and respirator use, were determined as covariates. The WHOQOL-BREF, was utilized to measure the dependent variable of this research: Quality of Life.

The four major domains assessed in the WHOQOL-BREF can be described as: 1. Physical Domain Score with 7 items, 2 . Psychological health with 6 items, 3. Social relationships with 3 items (Personal relationships; Sexual activity; Social support) and 4 Environmental health with 8 items. The responses to the questions are on a 1-5 Likert scale where 1 represents "disagree" or "not at all" and 5 represents "completely agree" or "extremely".

\section{Result}

Based on data from 172 participants in this research, table 1 shows the mean length of treatment (days) was $15.17 \pm 8$, while the mean length of the gap from baseline to interview (days) was $109.22 \pm 69.71$. Out of four quality of life domains, the lowest mean score was identified in the physical domain with $69.31 \pm$ 12.31 , while the highest score was indicated at the social domain with the mean of $78.29 \pm 16.08$. The mean score of the psychological and the environmental domain were $74.89 \pm 11.70$ and $73.60 \pm 13.30$, respectively.

\section{Demographic characteristics}

Table 2 describes the demographic characteristics of participants in this research. The proportion of males (48.3\%) and females (51.7\%) in this research tended to be equal. The majority of participants were aged $18-39$ years $(58, .1 \%)$, married or living with partners (66.9\%), and working in the private sector (55.2\%). Out of 172 participants, only 20 (11.6\%) used respiratory aids during their COVID-19 treatment. Among all participants, almost one-third (30.2\%) experienced long-haul symptoms of COVID symptoms, with $23.8 \%$ were having one symptom, and $6.4 \%$ were having two or more symptoms.

Further information on long-haul COVID are seen in Table 3. From eleven (11) symptoms that were collected, most of the participants experienced fatigue $(16.3 \%)$, chest pain $(7 \%)$, coughing $(4.1 \%)$, breathing trouble $(2.9 \%)$, as well as digestive disorder and headache (2.3\%). There were one to two participants who experienced other symptoms such as ageusia, anosmia, memory loss, nausea, and joint pain.

Table 4 presents a comparison of the average scores for each quality of life domain according to socio-demography, treatment history, and having Long-Haul COVID symptoms. The Comparison of the average of scores domains in Quality of life can be described that there was a difference in the average score of the social domain male higher rather than female groups (p-value 0.03). In the 18-39 year age group, the average psychological domain score was higher than the 40-year-old age group or older ( $p$-valu0.03). On the marital status of the participants, those who were married or living with a partner had a higher average psychological domain score than those from the single or divorced group ( $\mathrm{p}$-value 0.007). On the variable duration of treatment, there was no significant difference in the average in all domains of Quality of Life. However, regarding the use of breathing during COVID-19 treatment, the two Quality of Life domains (Psychological and Environmental) have a significant average difference with p-values of 0.01 and 0.02 , respectively. The other variables were not proven to be significant.

In Table 5, the Quality of Life variable was categorized into two categories (good and poor), as the scores were not normally distributed. Table 5 shows female participants, those aged 40 years or more, divorced/single participants, and unemployed participants tend to have a poorer quality of life in the physical domain. People with two or more symptoms of Long-Haul COVID also tended to have a poor quality of life in the physical domain compared to those without long-haul symptoms $(\mathrm{OR}=2.54,95 \% \mathrm{Cl}=0.68-9.46)$.

In the psychological domain, participants aged 40 years or more and participants with 14 or more days of treatment were two-fold more at risk to experience poor quality of life compared to their counterparts. Participants with two or more Long-Haul COVID symptoms also tended to have a higher risk for poorer quality of health in the psychological domain, with an odds ratio of 2.44 (95\% Cl $=0.46-12.89)$, compared to those who showed no symptoms.

In the social domain, people with one Long-Haul COVID symptoms have a higher risk, by almost two times, compared to those with no symptoms (OR $=1.97$, $95 \% \mathrm{Cl}=0.79-4.92$ ). In contradictory, Long-Haul COVID symptoms tended to be protective against the poor quality of life compared to those with no symptoms, in terms of the environmental domain. Thus, these initial results need to be analyzed further using multivariate analysis, as seen in Table 6 . Multivariate analysis with four models was presented in this research. In which, each model has one dependent variable from each domain of the Quality of Life.

After adjusted with other variables, people with Long-Haul COVID tend to be at a greater risk to have a poor quality of life in the physical domain, psychological domain, and social domain with an odds ratio of $1.93(95 \% \mathrm{Cl}=0.88-4.23), 2.62(95 \% \mathrm{Cl}=0.96-7.14)$, and $2.09(95 \% \mathrm{Cl}=0.85-5.12)$, respectively. With an odd ratio of 0.99 , the effect of Long-Haul COVID symptoms could not be concluded in the environmental domain.

\section{Discussion}

\section{The limitations of this research}

The limitation of this research is that the symptoms reported by the subjects were obtained through online questionnaires due to the government fieldwork. Therefore, these symptoms are subjective according to the perception of each individual. This research has a large proportion in the relatively young age group (under 40 years). Thus, persistent variation in symptoms according to age remains unknown. Notwithstanding that the patients are young and have a 
lower epidemiological propensity for chronic diseases and other degenerative symptoms, the symptoms of those who complain have a lower risk of the consequences of the chronic disease.

\section{The strength of this research}

Many people experience prolonged symptoms, poor health, and reduced function for months, even though they are not hospitalized for SARS-CoV-2 infection. This study explores the health condition of COVID 19 patients after discharge from the hospital and emphasizes the need for post-hospital surveillance as a necessity, as well as building sustainable health services as a recovery response from a quality of life perspective.

\section{Long-Haul COVID and Quality of life}

Quality of life is currently defined as a multidimensional concept consisting of a number of domains that people consider and evaluate differently according to the importance they attach to each domain in their lives.[17] In the condition of post-covid patients, it is interesting to explore the relationship with the four domains in the WHOQOL BREF as Quality of Life instrument. [8][This is important to clarify the post-hospital care steps that should be taken in upholding complete health related to the quality of life.

Furthermore, based on Epidemiological and immunological-based studies of recovered COVID 19 patients, it can be utilized to monitor their health status for possible future complications.[2][16] Observational investigations in larger cohorts will help us understand the deep prognosis and pathogenesis of COVID 19 disease. Studies of this kind will help uncover whether patients recovering from COVID 19 require post-acute care to recover from further infection or multiorgan damage.[18] SARS-CoV-2 mainly affects people who are immunocompromised and have previous medical conditions (problems related to the lungs, kidneys, heart, and digestive tract).[19][20] Our research showed that almost one-third (30.2\%) experienced long-haul symptoms of COVID 19, with 23.8\% experiencing one symptom and $6.4 \%$ experiencing two or more symptoms, in which most of them have experienced fatigue, chest pain, coughing, breathing trouble, digestive disorder and headache $(16.3 \% ; 7 \% ; 4.1 \% ; 2.9 \% ; 2.3 \%)$, respectively.

Further, after the Quality of Life variable was categorized into two categories (good and poor), it was implied how the long-haul symptoms affect all domains, except for the environmental one. It was found that those who had remote covid symptoms and had more than one symptom are at approximately double the risk of having poor quality of life compared with those without symptoms. In addition, the risk of having a bad quality of life varied greatly depending on the predominance. However, the increasing risk of having poor quality of life from the use of respirators is seen in none of the domains. Respondents aged 40 years or over are more at risk of having poor quality of life in physical and psychological aspects of Quality of Life. In addition, women and unmarried or divorced respondents are also at risk of having poor quality of life in the physical domain. Length of stay of more than 14 days also renders poor Quality of Life in the psychological domain. In the social domain, unmarried or divorced status, as well as the type of work seems to affect the risk of having poor quality of life.In the environmental domain, women respondents, those with single or divorced status, and those with a length of stay of more than 14 days are at risk of having a bad quality of life.

Results of multivariate analysis implied that Long-Haul COVID patients tend to have a greater risk of having poor Quality of Life in the physical domain, psychological domain, and social domain with odds ratios of $1.93(95 \% \mathrm{Cl}=0.88-4.23), 2.62(95 \% \mathrm{Cl}=0.96-7.14)$, and $2.09(95 \% \mathrm{Cl}=0.85-5,12)$. The environmental domain has an odd ratio of 0.99 , which seems to be a protective effect for poor Quality of Life. The significant impact of the emergence of Long-Haul COVID on recovered patients confirmed the association between the Long-Haul COVID and the WHOQOL-BREF Quality of IIFE domains. [21] The findings are essential to clarify the necessary steps for post-hospital care that need to be taken to create a whole and quality-related health[22][23].

\section{Conclusion}

Those who have recovered from COVID-19 still have health problems such as long-haul COVID 19 symptoms. Many of them are also related to the reduction of the quality of life domain. If left untreated, they will continue to experience long-term health complications. Therefore, robust post-hospital surveillance is needed to identify the need for related health services.

\section{Declarations}

\section{Ethics approval and consent to participate}

This study obtained ethical clearance from Universitas Indonesia's Ethics Committee, with Ethical Approval number: 593/UN2.F10.D11/PPM.00.02/2020

\section{Patient consent for publication}

\section{Informed consent}

Informed consent was given in the beginning of the questionnaire, in which participants agreed or declined to take part in the study. 
The datasets used and/or analyzed during the current study are available from the corresponding author on reasonable request. The contact to request is to the corresponding author dini05@ui.ac.id.

\section{Competing interests}

The authors declare that there are no competing interests.

\section{Funding}

This research was supported by the International Indexed Publication Grant (PUTI) for Q2 Fiscal Year 2020 Number: NKB-1626/UN2.RST/HKP.05.00/2020 Universitas Indonesia.

\section{Authors' contributions}

The conceptualized design of the study was IT. IT, MM, DAKS and CPE collected the data, contributed to the analysis of the data, and interpreted the results. IT, MM, and CPE prepared the draft of the manuscript. IT was a major contributor in writing the manuscript, especially in methodology, discusion, and conclusion. All authors read and approved the final manuscript.

\section{Acknowledgements}

The authors would like to thank the respondents that filled out the online questionnaire and the Health Agency of DKI Jakarta for their permit and assistance in the collection of the data.

\section{Authors' information (optional)}

Indang Trihandini ('IT') is working at Biostatistics and Population Studies Department, Faculty of Public Health, Universitas Indonesia as a lecturer and researcher.

Manendra Muhtar ('MM') was a master's program student, Faculty of Public Health, Universitas Indonesia, already graduated in 2021.

Dea Allan Karunia Sakti ('DAKS') was a master's program student, Faculty of Public Health, Universitas Indonesia, already graduated in 2021.

Chintya Putri Erlianti ('CPE') was an undergraduate student, Faculty of Public Health, Universitas Indonesia, already graduated in 2021.

\section{Abbreviations}

Long-Haul COVID, also known as post-COVID-19 syndrome, post-acute sequelae of COVID-19 (PASC), or chronic COVID syndrome (CCS).

\section{References}

1. Logue JK, Franko NM, McCulloch DJ, et al. Sequelae in adults at 6 months after COVID-19 infection. 2021. JAMA Network Open. 2021;4(2):e210830. Doi:10.1001/jamanetworkopen.2021.0830

2. Angelo Carfi, Roberto Bernabei,Francesco Landi. Persistent symptoms in patients after acute COVID-19. 2020. J. Am. Med. Assoc. 324, $603-605$. Doi:10.1001/jama.2020.12603

3. Davis, H. E., Assaf, G. S., McCorkell, L., Wei, H., Low, R. J., Re'em, Y., et al. Characterizing long COVID in an international cohort: 7 months of symptoms and their impact. 2020. Doi: 10.1101/2020.12.24.20248802

4. Huang, Y., Pinto, M. D., Borelli, J. L., Mehrabadi, M. A., Abrihim, H., Dutt, N., et al. COVID symptoms, symptom clusters, and predictors for becoming a longhauler: looking for clarity in the haze of the pandemic. 2021. medRxiv [Preprint] Doi: 10.1101/2021.03.03.21252086

5. Hamid Reza Niazkar, Behdad Zibaee1 \& Ali Nasimi1 \& Narjes B The neurological manifestations of COVID-19: a review article. Neurological Sciences. 41 (7): 1667-1671. July 2020. Doi:10.1007/s10072-020-04486-3

6. Anthony L. Komaroff, Lucinda Bateman. Will COVID-19 Lead to Myalgic Encephalomyelitis/Chronic Fatigue Syndrome?. Frontiers in Medicine, 1 January 2021, Volume 7, Article 606824

7. Bjørn Blomberg, Kristin Greve-Isdahl Mohn, Karl Albert Brokstad, Fan Zhou, Dagrun Waag Linchausen, Bent-Are Hansen. et al. Long COVID in a prospective cohort of home-isolated patients. Nature Medicine, VOL 27,September 2021, 1607-1613

8. Suzanne Skevington, Mahmoud Lotfy, Kathryn A. O'Connell. The World Health Organization's WHOQOL-BREF quality of life assessment: Psychometric properties and results of the international field trial A Report from the WHOQOL Group. Quality of Life Research 13: 299-310, 2004

9. WHO. Division Of Mental Health And Prevention of Substance Abuse. WHOQOL User Manual. WHO/HIS/HIS Rev.2012.03 
10. The WHOQOL group. Development of the World Health Organization WHOQOL-BREF quality of life assessment. Psychol Med 1998; May (3):551-8. doi: $10.1017 / \mathrm{s} 0033291798006667$

11. Nørholm, V. and Bech, P. The WHO Quality of Life (WHOQOL) Questionnaire Danish Validation Study. Nordic Journal of Psychiatry, $2001,55,229-235$.

12. Graeme Hawthorne, Helen Herrman, Barbara Murphy. INTERPRETING THE WHOQOL-BRE` F: PRELIMINARY POPULATION NORMS AND EFFECT SIZES. Springer 2006. Social Indicators Research (2006) 77:37-59. doi 10.1007/s11205-005-5552-1

13. Fredrick Dermawan Purba, Joke A. M. Hunfeld, Aulia Iskandarsyah, Titi Sahidah Fitriana, Sawitri S. Sadarjoen, Jan Passchier, Jan J. V. Busschbach. Quality of life of the Indonesian general population: Test-retest reliability and population norms of the EQ-5D-5L and WHOQOL-BREF. PLOS ONE. May 11, 2018. Doi:10.1371/journal.pone.0197098

14. Latifa Resmiya, Ifa H, M. Pengembangan Alat Ukur Kualitas Hidup Indonesia. Jurnal Psikologi Insight, Vol 3, No 1 (2019). Doi: $10.17509 /$ Insight.V3i1.22247

15. Nadya Ayudiawati Nurbasari, Lazuardhi Dwipa, Sharon Gondodiputro. The Elderly's Quality Of Life In The Panti Werdha And The Community Of Bandung City: Whoqol-Bref And Whoqol-Old Indonesian Version. Share Social Work Journal, Vol 9, No 2 (2019). Doi: 10.24198/Share.V9i2.25611

16. Vellingiri Balachandar, lyer Mahalaxmi, Mohandevi Subramaniam, Jayaramayya Kaavya, Nachimuthu Senthil Kumar, et al. Follow-up studies in COVID-19 recovered patients - is it mandatory?. Sci Total Environ. 2020 Aug 10; 729: 139021. Doi: 10.1016/j.scitotenv.2020.139021

17. Paraskevi Theofilou. Quality of Life: Definition and Measurement. Europe's Journal of Psychology 2013, Vol. 9(1), 150-162. Doi:10.5964/ejop.v9i1.337

18. Graziella Orrù, Davide Bertelloni, Francesca Diolaiuti, Federico Mucci, Mariagrazia Di Giuseppe, Marco Biella, Angelo Gemignani, Rebecca Ciacchini and Ciro Conversano. Long-COVID Syndrome? A Study on the Persistence of Neurological, Psychological and Physiological Symptoms. Healthcare 2021, 9 , 575. Doi: 10.3390/healthcare9050575

19. Al-Aly Z, Xie Y, Bowe B. High-dimensional characterization of post-acute sequelae of COVID Nature. Juli 2021, 594 (7862): 259-264. Doi:10.1038/s41586021-03553-9

20. Ana Luiza Cabrera Martimbianco, Rafael Leite Pacheco, Ângela Maria Bagattini, Rachel Riera. Frequency, signs and symptoms, and criteria adopted for long COVID-19: A systematic review. The International Journal of Clinical Practice, 2021;75:e14357. Doi:10.1111/ijcp.14357

21. Baig AM. Chronic COVID syndrome: Need for an appropriate medical terminology for long-COVID and COVID long-haulers. Journal of Medical Virology. May 2021, 93 (5): 2555-56. Doi:10.1002/jmv.26624

22. Bodunrin Osikomaiya, Olufemi Erinoso, Kikelomo Ololade Wright, Aina Olufemi Odusola, Babafemi Thomas, Oluwatosin Adeyemi, Abimbola Bowale, Olusola Adejumo, Ayodeji Falana, Ismail Abdus-salam, Olusegun Ogboye, Akin Osibogun and Akin Abayomi. Long COVID': persistent COVID-19 symptoms in survivors managed in Lagos State, Nigeria. BMC Infectious Diseases 2021, 21:304. Doi: 10.1186/s12879-020-05716-x

23. Trisha Greenhalgh, Matthew Knight, Christine A'Court, Maria Buxton, Laiba Husain. Management of post-acute covid-19 in primary care. BMJ 2020, 70:m3026. doi: 10.1136/bmj.m3026

\section{Tables}

Table 1. Descriptive statistics of Length of Treatment, Length from Onset to Interview, Quality of Life domains,

\begin{tabular}{lllll} 
Variable & Mean & SD & Min. & Max. \\
\hline Length of Treatment (day) & 15,17 & 8,00 & 7 & 42 \\
\hline Length from Onset to Interview (day) & 109,22 & 69,72 & 29 & 309 \\
\hline WHOQOL Physical Domain Score & 69,31 & 12,31 & 35,71 & 100 \\
\hline WHOQOL Psychological Domain Score & 74,44 & 11,60 & 45,83 & 100 \\
\hline WHOQOL Social Domain Score & 78,29 & 16,08 & 16,67 & 100 \\
\hline WHOQOL Environmental Domain Score & 73,62 & 13,53 & 43,75 & 100
\end{tabular}

Table 2. The Demographic characteristics, History of treatments and The Long-Haul COVID 19 


\begin{tabular}{|c|c|c|}
\hline No & Variables & Frequencies (\%) \\
\hline \multirow[t]{3}{*}{1} & Gender & \\
\hline & Male & $83(48.3 \%)$ \\
\hline & Female & $89(51.7 \%)$ \\
\hline \multirow[t]{3}{*}{2} & Age Group & \\
\hline & 18 - 39 years old & $100(58.1 \%)$ \\
\hline & $\geq 40$ years old & $72(41.9 \%)$ \\
\hline \multirow[t]{3}{*}{3} & Marital Status & \\
\hline & Married/Living with Partner & $115(66.9 \%)$ \\
\hline & Divorced/ Single & $57(33.1 \%)$ \\
\hline \multirow[t]{4}{*}{4} & Occupation & \\
\hline & Civil Servant \& Police \& Army & $41(23.8 \%)$ \\
\hline & Private Sector & $95(55.2 \%)$ \\
\hline & Unemployed & $36(20.9 \%)$ \\
\hline \multirow[t]{3}{*}{5} & Length of Treatment & \\
\hline & $\leq 13$ days $(<2$ weeks $)$ & $71(41.3 \%)$ \\
\hline & $\geq 14$ days ( $\geq 2$ weeks) & $101(58.7 \%)$ \\
\hline \multirow[t]{3}{*}{6} & Respiratory Used & \\
\hline & No & $152(88.4 \%)$ \\
\hline & Yes & $20(11.6 \%)$ \\
\hline \multirow[t]{3}{*}{7} & Length from Onset (to Interview) & \\
\hline & $\leq 3$ months & $92(53.5 \%)$ \\
\hline & $>3$ months & $80(46.5 \%)$ \\
\hline \multirow[t]{3}{*}{8} & Long-Haul COVID 19 & \\
\hline & No & $120(69.8 \%)$ \\
\hline & Yes & $52(30.2 \%)$ \\
\hline \multirow[t]{4}{*}{9} & Number of Long-Haul COVID 19 & \\
\hline & No & $120(69.8 \%)$ \\
\hline & 1 Symptom & $41(23.8 \%)$ \\
\hline & > 1 Symptom & $11(6.4 \%)$ \\
\hline
\end{tabular}

Table 3. The list of The Long-Haul COVID 19 symptomps 


\begin{tabular}{|c|c|c|}
\hline No & Variables & Frequencies (\%) \\
\hline \multirow[t]{3}{*}{1} & Coughing & \\
\hline & No & $165(95.9 \%)$ \\
\hline & Yes & $7(4.1 \%)$ \\
\hline \multirow[t]{3}{*}{2} & Digestive Disorder & \\
\hline & No & $168(97.7 \%)$ \\
\hline & Yes & $4(2.3 \%)$ \\
\hline \multirow[t]{3}{*}{3} & Ageusia & \\
\hline & No & $169(98.3 \%)$ \\
\hline & Yes & $3(1.7 \%)$ \\
\hline \multirow[t]{3}{*}{4} & Anosmia & \\
\hline & No & $170(98.8 \%)$ \\
\hline & Yes & $2(1.2 \%)$ \\
\hline \multirow[t]{3}{*}{5} & Headache & \\
\hline & No & $168(97.7 \%)$ \\
\hline & Yes & $4(2.3 \%)$ \\
\hline \multirow[t]{3}{*}{6} & Memory Loss & \\
\hline & No & $171(99.4 \%)$ \\
\hline & Yes & $1(0.6 \%)$ \\
\hline \multirow[t]{3}{*}{7} & Nausea & \\
\hline & No & $170(98.8 \%)$ \\
\hline & Yes & $2(1.2 \%)$ \\
\hline \multirow[t]{3}{*}{8} & Joint Pain & \\
\hline & No & $171(99.4 \%)$ \\
\hline & Yes & $1(0.6 \%)$ \\
\hline \multirow[t]{3}{*}{9} & Fatigue & \\
\hline & No & $144(83.7 \%)$ \\
\hline & Yes & $28(16.3 \%)$ \\
\hline \multirow[t]{3}{*}{10} & Breathing Trouble & \\
\hline & No & $167(97.1 \%)$ \\
\hline & Yes & $5(2.9 \%)$ \\
\hline \multirow[t]{3}{*}{11} & ChestPain & \\
\hline & No & $160(93.0 \%)$ \\
\hline & Yes & $12(7.0 \%)$ \\
\hline
\end{tabular}

Table 4. The quality of life domain scores for sociodemographic and health-related predictors 
Physical Domain Score

\begin{tabular}{lll} 
Score & $95 \% \mathrm{Cl}$ & $\mathrm{P}$ \\
\cline { 2 - 3 } & Lower & Upper
\end{tabular}

Psychological Domain Score

Score $95 \% \mathrm{Cl}$

Lower Upper
Social Domain Score

Score $\quad 95 \% \mathrm{Cl}$

Lower Upper
Environme

Score 9!

L

Gender

\begin{tabular}{|c|c|c|c|c|c|c|c|c|c|c|c|c|c|c|}
\hline Male & $83(48.3 \%)$ & $\begin{array}{l}70.22 \\
\pm \\
11.99\end{array}$ & 67,60 & 72,84 & 0,35 & $\begin{array}{l}74.99 \\
\pm \\
12.03\end{array}$ & 72,37 & 77,63 & 0,54 & $\begin{array}{l}81.02 \\
\pm \\
15.30\end{array}$ & 77,68 & 84,37 & $0.03^{*}$ & $\begin{array}{l}74.96 \\
\pm \\
12.67\end{array}$ \\
\hline Female & 89 (51.7\%) & $\begin{array}{l}68.46 \\
\pm \\
12.61\end{array}$ & 65,80 & 71,11 & & $\begin{array}{l}73.92 \\
\pm \\
11.23\end{array}$ & 71,56 & 76,29 & & $\begin{array}{l}75.75 \\
\pm \\
16.46\end{array}$ & 72,28 & 79,22 & & $\begin{array}{l}72.37 \\
\pm \\
14.23\end{array}$ \\
\hline
\end{tabular}

Age Group

\begin{tabular}{|c|c|c|c|c|c|c|c|c|c|c|c|c|c|c|}
\hline $\begin{array}{l}18 \text { - } 39 \text { years } \\
\text { old }\end{array}$ & $100(58.1 \%)$ & $\begin{array}{l}70.86 \\
\pm \\
12.56\end{array}$ & 68,37 & 73,35 & 0,052 & $\begin{array}{c}76.04 \\
\pm \\
11.41\end{array}$ & 73,78 & 78,31 & $0.03 *$ & $\begin{array}{c}79.25 \\
\pm \\
16.65\end{array}$ & 75,95 & 82,55 & 0,36 & $\begin{array}{c}73.72 \\
\pm \\
13.88\end{array}$ \\
\hline$\geq 40$ years old & 72 (41.9\%) & $\begin{array}{l}67.16 \\
\pm \\
11.71\end{array}$ & 64,41 & 69,91 & & $\begin{array}{c}72.22 \\
\pm \\
11.58\end{array}$ & 69,50 & 74,94 & & $\begin{array}{l}79.97 \\
\pm \\
15.29\end{array}$ & 73,37 & 80,56 & & $\begin{array}{c}73.48 \\
\pm \\
13.11\end{array}$ \\
\hline
\end{tabular}

Marital Status

\begin{tabular}{|c|c|c|c|c|c|c|c|c|c|c|c|c|c|c|}
\hline $\begin{array}{l}\text { Married/Living } \\
\text { with Partner }\end{array}$ & 115 (66.9\%) & $\begin{array}{l}68.91 \\
\pm \\
11.59\end{array}$ & 66,77 & 71,05 & 0,55 & $\begin{array}{l}73.26 \\
\pm \\
10.99\end{array}$ & 71,23 & 75,29 & 0,06 & $\begin{array}{l}80.87 \\
\pm \\
13.87\end{array}$ & 78,31 & 83,43 & $0.007^{*}$ & $\begin{array}{l}73.45 \\
\pm \\
12.74\end{array}$ \\
\hline $\begin{array}{l}\text { Divorced/ } \\
\text { Single }\end{array}$ & 57 (33.1\%) & $\begin{array}{l}70.11 \\
\pm \\
13.73\end{array}$ & 66,47 & 73,75 & & $\begin{array}{c}76.83 \\
\pm \\
12.50\end{array}$ & 73,51 & 80,14 & & $\begin{array}{c}73.10 \\
\pm \\
18.89\end{array}$ & 68,08 & 78,11 & & $\begin{array}{c}73.96 \\
\pm \\
15.11\end{array}$ \\
\hline
\end{tabular}

Occupation

Civil Servant \&

Police \& Army

$41(23.8 \%)$

$\begin{array}{llll}68.90 & 64,86 & 72,95 & 0,51\end{array}$

$\begin{array}{llll}73.88 & 70,44 & 77,32 & 0,94\end{array}$

$\begin{array}{llllll}81.71 & 77,18 & 86,23 & 0,30 & 75.54 & 7\end{array}$ \pm
12.81
10.91

$\stackrel{ \pm}{14.34}$

$\pm$

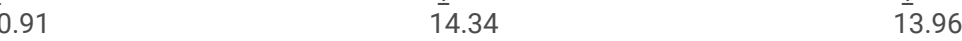

Private Sector

$70.19 \quad 67,87 \quad 72,51$

$74.65 \quad 72,39 \quad 76,90$

$77.19 \quad 73,94 \quad 80,44$

$72.47 \quad 6$

$\stackrel{ \pm}{11.07}$

$\stackrel{ \pm}{15.95}$

$\stackrel{ \pm}{13.07}$

Unemployed

$36(20.9 \%) \quad 67.46 \quad 62,69 \quad 72,23$

$74.54 \quad 69,85 \quad 79,23$

$\pm$

$77.31 \quad 71,19 \quad 83,44$

$\pm$

$74.48 \quad 6 !$

$\stackrel{ \pm}{14.28}$

Length of

Treatment

\begin{tabular}{|c|c|c|c|c|c|c|c|c|c|c|c|c|c|c|}
\hline $\begin{array}{l}1-13 \text { days (<2 } \\
\text { weeks) }\end{array}$ & 71 (41.3\%) & $\begin{array}{l}69.67 \\
\pm \\
11.94\end{array}$ & 66,84 & 72,49 & 0,75 & $\begin{array}{l}74.29 \\
\pm \\
10.08\end{array}$ & 71,91 & 76,68 & 0,89 & $\begin{array}{l}80.16 \\
\pm \\
15.39\end{array}$ & 76,52 & 83,81 & 0,20 & $\begin{array}{l}73.86 \\
\pm \\
12.92\end{array}$ \\
\hline $\begin{array}{l}\geq 14 \text { days ( } \geq 2 \\
\text { weeks) }\end{array}$ & 101 (58.7\%) & $\begin{array}{l}69.06 \\
\pm \\
12.62\end{array}$ & 66,57 & 71,55 & & $\begin{array}{l}74.55 \\
\pm \\
12.61\end{array}$ & 72,06 & 77,03 & & $\begin{array}{l}76.98 \\
\pm \\
16.50\end{array}$ & 73,72 & 80,24 & & $\begin{array}{l}73.45 \\
\pm \\
14.00\end{array}$ \\
\hline
\end{tabular}

Respiratory

Used

\begin{tabular}{|c|c|c|c|c|c|c|c|c|c|c|c|c|c|c|}
\hline No & 152 (88.4\%) & $\begin{array}{l}68.75 \\
\pm \\
12.08\end{array}$ & 66,81 & 70,68 & 0,10 & $\begin{array}{l}73.63 \\
\pm \\
11.46\end{array}$ & 71,79 & 75,47 & $0.01 *$ & $\begin{array}{l}77.63 \\
\pm \\
16.62\end{array}$ & 74,97 & 80,30 & 0,14 & $\begin{array}{l}72.78 \\
\pm \\
13.53\end{array}$ \\
\hline Yes & 20 (11.6\%) & $\begin{array}{l}73.57 \\
\pm \\
13.53\end{array}$ & 67,24 & 79,90 & & $\begin{array}{l}80.62 \\
\pm \\
11.00\end{array}$ & 75,47 & 85,77 & & $\begin{array}{l}83.33 \\
\pm \\
10.12\end{array}$ & 78,60 & 88,07 & & $\begin{array}{l}80.00 \\
\pm \\
11.97\end{array}$ \\
\hline
\end{tabular}

Length from

Onset (to

Interview)

\begin{tabular}{|c|c|c|c|c|c|c|c|c|c|c|c|c|c|c|}
\hline$\leq 3$ months & 92 (53.5\%) & $\begin{array}{l}67.90 \\
\pm \\
12.14\end{array}$ & 65,38 & 70,41 & 0,11 & $\begin{array}{c}73.41 \\
\pm \\
11.32\end{array}$ & 71,07 & 75,76 & 0,21 & $\begin{array}{c}76.54 \\
\pm \\
14.40\end{array}$ & 73,56 & 79,52 & 0,12 & $\begin{array}{c}72.86 \\
\pm \\
13.15\end{array}$ \\
\hline$>3$ months & 80 (46.5\%) & $\begin{array}{l}70.94 \\
\pm \\
12.38\end{array}$ & 68,18 & 73,69 & & $\begin{array}{c}75.62 \\
\pm \\
11.88\end{array}$ & 72,98 & 78,27 & & $\begin{array}{c}80.31 \\
\pm \\
17.70\end{array}$ & 76,37 & 84,25 & & $\begin{array}{c}74.49 \\
\pm \\
13.98\end{array}$ \\
\hline
\end{tabular}




\begin{tabular}{|c|c|c|c|c|c|c|c|c|c|c|c|c|c|c|}
\hline No & $120(69.8 \%)$ & $\begin{array}{l}70.12 \\
\pm \\
12.41\end{array}$ & 67,88 & 72,36 & 0,19 & $\begin{array}{l}74.99 \\
\pm \\
11.29\end{array}$ & 72,96 & 77,04 & 0,34 & $\begin{array}{l}78.89 \\
\pm \\
15.84\end{array}$ & 76,03 & 81,75 & 0,46 & $\begin{array}{l}73.52 \\
\pm \\
13.68\end{array}$ \\
\hline Yes & $52(30.2 \%)$ & $\begin{array}{l}67.44 \\
\pm \\
11.99\end{array}$ & 64,10 & 70,78 & & $\begin{array}{l}73.16 \\
\pm \\
12.30\end{array}$ & 69,73 & 76,58 & & $\begin{array}{l}76.92 \\
\pm \\
16.72\end{array}$ & 72,27 & 81,57 & & $\begin{array}{l}73.86 \\
\pm \\
13.29\end{array}$ \\
\hline
\end{tabular}

Number of

Long-Haul

COVID 19

\begin{tabular}{|c|c|c|c|c|c|c|c|c|c|c|c|c|c|c|c|}
\hline No & $120(69.8 \%)$ & $\begin{array}{l}70.12 \\
\pm \\
12.41\end{array}$ & 67,88 & 72,36 & 0,37 & $\begin{array}{l}74.99 \\
\pm \\
11.29\end{array}$ & 72,96 & 77,04 & 0,49 & $\begin{array}{l}78.89 \\
\pm \\
15.84\end{array}$ & 76,03 & 81,75 & 0,70 & $\begin{array}{l}73.52 \\
\pm \\
13.68\end{array}$ & $7^{\circ}$ \\
\hline 1 Symptom & 41 (23.8\%) & $\begin{array}{l}66.99 \\
\pm \\
10.91\end{array}$ & 63,54 & 70,43 & & $\begin{array}{l}72.56 \\
\pm \\
11.71\end{array}$ & 68,86 & 76,26 & & $\begin{array}{l}76.42 \\
\pm \\
16.86\end{array}$ & 71,10 & 81,75 & & $\begin{array}{l}72.64 \\
\pm \\
12.61\end{array}$ & $6\}$ \\
\hline > 1 Symptom & $11(6.4 \%)$ & $\begin{array}{l}69.15 \\
\pm \\
15.91\end{array}$ & 58,46 & 79,85 & & $\begin{array}{l}75.38 \\
\pm \\
14.73\end{array}$ & 65,48 & 85,27 & & $\begin{array}{l}78.79 \\
\pm \\
16.82\end{array}$ & 67,49 & 90,09 & & $\begin{array}{l}78.41 \\
\pm \\
15.34\end{array}$ & $6\}$ \\
\hline
\end{tabular}

Table 5. The association of quality of life domain category related by sociodemographic and health-related predictors 
OR

Psychological

OR

\section{Bad Good}

$(95 \% \mathrm{Cl})$

Domain Category $\quad(95 \% \mathrm{Cl})$

Category

Bad Good

Bad

(\%)

(\%)

$83(48.3 \%)$

15

Male

$83(48.3 \%)$

$\begin{array}{ll}15 & 68 \\ (18.1 \%) & (81.9 \%)\end{array}$

Female

$89(51.7 \%)$

$\begin{array}{lll}22 & 67 & 1.4 \\ (24.7 \%) & (75.3 \%) & (0.7\end{array}$

Age Group (2

categories)

\begin{tabular}{|c|c|c|c|c|c|c|c|c|c|c|c|c|}
\hline $\begin{array}{l}18 \text { - } 39 \text { years } \\
\text { old }\end{array}$ & $100(58.1 \%)$ & $\begin{array}{l}18 \\
(18.0 \%)\end{array}$ & $\begin{array}{l}82 \\
(82.0 \%)\end{array}$ & 1 (Ref) & $\begin{array}{l}7 \\
(7.0 \%)\end{array}$ & $\begin{array}{l}93 \\
(93.0 \%)\end{array}$ & 1 (Ref) & $\begin{array}{l}16 \\
(16.0 \%)\end{array}$ & $\begin{array}{l}84 \\
(84.0 \%)\end{array}$ & 1 (Ref) & $\begin{array}{l}21 \\
(21.0 \%)\end{array}$ & $\begin{array}{l}79 \\
(79.0 \%)\end{array}$ \\
\hline$\geq 40$ years old & $72(41.9 \%)$ & $\begin{array}{l}19 \\
(26.4 \%)\end{array}$ & $\begin{array}{l}53 \\
(73.6 \%)\end{array}$ & $\begin{array}{l}1.63 \\
(0.79- \\
3.39)\end{array}$ & $\begin{array}{l}12 \\
(16.7 \%)\end{array}$ & $\begin{array}{l}60 \\
(83.3 \%)\end{array}$ & $\begin{array}{l}2.66 \\
(0.99- \\
7.13)\end{array}$ & $\begin{array}{l}10 \\
(13.9 \%)\end{array}$ & $\begin{array}{l}62 \\
(86.1 \%)\end{array}$ & $\begin{array}{l}0.85 \\
(0.36- \\
1.99)\end{array}$ & $\begin{array}{l}13 \\
(18.1 \%)\end{array}$ & $\begin{array}{l}59 \\
(81.9 \%)\end{array}$ \\
\hline
\end{tabular}

Marital Status

\begin{tabular}{|c|c|c|c|c|c|c|c|c|c|c|c|c|}
\hline $\begin{array}{l}\text { Married/Living } \\
\text { with Partner }\end{array}$ & 115 (66.9\%) & $\begin{array}{l}22 \\
(19.1 \%)\end{array}$ & $\begin{array}{l}93 \\
(90.3 \%)\end{array}$ & 1 (Ref) & $\begin{array}{l}14 \\
(12.2 \%)\end{array}$ & $\begin{array}{l}101 \\
(87.8 \%)\end{array}$ & 1 (Ref) & $\begin{array}{l}12 \\
(10.4 \%)\end{array}$ & $\begin{array}{l}103 \\
(89.6 \%)\end{array}$ & 1 (Ref) & $\begin{array}{l}19 \\
(16.5 \%)\end{array}$ & $\begin{array}{l}96 \\
(83.5 \%)\end{array}$ \\
\hline $\begin{array}{l}\text { Divorced/ } \\
\text { Single }\end{array}$ & 57 (33.1\%) & $\begin{array}{l}15 \\
(26.3 \%)\end{array}$ & $\begin{array}{l}42 \\
(73.7 \%)\end{array}$ & $\begin{array}{l}1.51 \\
(0.71- \\
3.20)\end{array}$ & $\begin{array}{l}5 \\
(8.8 \%)\end{array}$ & $\begin{array}{l}52 \\
(91.2 \%)\end{array}$ & $\begin{array}{l}0.69 \\
(0 . .24- \\
2.03)\end{array}$ & $\begin{array}{l}14 \\
(24.6 \%)\end{array}$ & $\begin{array}{l}43 \\
(75.4 \%)\end{array}$ & $\begin{array}{l}2.79 \\
(1.19- \\
6.53)\end{array}$ & $\begin{array}{l}15 \\
(26.3 \%)\end{array}$ & $\begin{array}{l}42 \\
(73.7 \%)\end{array}$ \\
\hline
\end{tabular}

Occupation

\begin{tabular}{|c|c|c|c|c|c|c|c|c|c|c|c|c|}
\hline $\begin{array}{l}\text { Civil Servant \& } \\
\text { Police \& Army }\end{array}$ & 41 (23.8\%) & $\begin{array}{l}10 \\
(24.4 \%)\end{array}$ & $\begin{array}{l}31 \\
(75.6 \%)\end{array}$ & 1 (Ref) & $\begin{array}{l}5 \\
(12.2 \%)\end{array}$ & $\begin{array}{l}36 \\
(87.8 \%)\end{array}$ & 1 (Ref) & $\begin{array}{l}5 \\
(12.2 \%)\end{array}$ & $\begin{array}{l}36 \\
(87.8 \%)\end{array}$ & 1 (Ref) & $\begin{array}{l}8 \\
(19.5 \%)\end{array}$ & $\begin{array}{l}33 \\
(80.5 \%)\end{array}$ \\
\hline Private Sector & 95 (55.2\%) & $\begin{array}{l}16 \\
(16.8 \%)\end{array}$ & $\begin{array}{l}79 \\
(83.2 \%)\end{array}$ & $\begin{array}{l}0.63 \\
(0.26- \\
1.53)\end{array}$ & $\begin{array}{l}10 \\
(10.5 \%)\end{array}$ & $\begin{array}{l}85 \\
(89.5 \%)\end{array}$ & $\begin{array}{l}0.85 \\
(0.27- \\
2.65)\end{array}$ & $\begin{array}{l}15 \\
(15.8 \%)\end{array}$ & $\begin{array}{l}80 \\
(84.2 \%)\end{array}$ & $\begin{array}{l}1.35 \\
(0.46- \\
3.99)\end{array}$ & $\begin{array}{l}19 \\
(20.0 \%)\end{array}$ & $\begin{array}{l}76 \\
(80.0 \%)\end{array}$ \\
\hline Unemployed & $36(20.9 \%)$ & $\begin{array}{l}11 \\
(30.6 \%)\end{array}$ & $\begin{array}{l}25 \\
(69.4 \%)\end{array}$ & $\begin{array}{l}1.36 \\
(0.50- \\
3.73)\end{array}$ & $\begin{array}{l}4 \\
(11.1 \%)\end{array}$ & $\begin{array}{l}32 \\
(88.9 \%)\end{array}$ & $\begin{array}{l}0.90 \\
(0.22- \\
3.64)\end{array}$ & $\begin{array}{l}6 \\
(16.7 \%)\end{array}$ & $\begin{array}{l}30 \\
(83.3 \%)\end{array}$ & $\begin{array}{l}1.44 \\
(0.40- \\
5.19)\end{array}$ & $\begin{array}{l}7 \\
(19.4 \%)\end{array}$ & $\begin{array}{l}29 \\
(80.6 \%)\end{array}$ \\
\hline
\end{tabular}

Length of

Care/Treatment

\begin{tabular}{|c|c|c|c|c|c|c|c|c|c|c|c|c|}
\hline $\begin{array}{l}1-13 \text { days (<2 } \\
\text { weeks) }\end{array}$ & $71(41.3 \%)$ & $\begin{array}{l}14 \\
(19.7 \%)\end{array}$ & $\begin{array}{l}57 \\
(80.3 \%)\end{array}$ & 1 (Ref) & $\begin{array}{l}5 \\
(7.0 \%)\end{array}$ & $\begin{array}{l}66 \\
(93.0 \%)\end{array}$ & 1 (Ref) & $\begin{array}{l}10 \\
(14.1 \%)\end{array}$ & $\begin{array}{l}61 \\
(85.9 \%)\end{array}$ & 1 (Ref) & $\begin{array}{l}11 \\
(15.5 \%)\end{array}$ & $\begin{array}{l}60 \\
(84.5 \%)\end{array}$ \\
\hline $\begin{array}{l}\geq 14 \text { days ( } \geq 2 \\
\text { weeks) }\end{array}$ & 101 (58.7\%) & $\begin{array}{l}23 \\
(22.8 \%)\end{array}$ & $\begin{array}{l}78 \\
(77.2 \%)\end{array}$ & $\begin{array}{l}1.20 \\
(0.57- \\
2.53)\end{array}$ & $\begin{array}{l}14 \\
(13.9 \%)\end{array}$ & $\begin{array}{l}87 \\
(86.1 \%)\end{array}$ & $\begin{array}{l}2.12 \\
(0.73- \\
6.19)\end{array}$ & $\begin{array}{l}16 \\
(15.8 \%)\end{array}$ & $\begin{array}{l}85 \\
(84.2 \%)\end{array}$ & $\begin{array}{l}1.15 \\
(0.49- \\
2.70)\end{array}$ & $\begin{array}{l}23 \\
(22.8 \%)\end{array}$ & $\begin{array}{l}78 \\
(77.2 \%)\end{array}$ \\
\hline
\end{tabular}

Respiratory

Used

\begin{tabular}{|c|c|c|c|c|c|c|c|c|c|c|c|c|}
\hline No & $152(88.4 \%)$ & $\begin{array}{l}34 \\
(22.4 \%)\end{array}$ & $\begin{array}{l}118 \\
(77.6 \%)\end{array}$ & 1 (Ref) & $\begin{array}{l}18 \\
(11.8 \%)\end{array}$ & $\begin{array}{l}134 \\
(88.2 \%)\end{array}$ & 1 (Ref) & $\begin{array}{l}26 \\
(17.1 \%)\end{array}$ & $\begin{array}{l}126 \\
(82.9 \%)\end{array}$ & 1 (Ref) & $\begin{array}{l}33 \\
(21.7 \%)\end{array}$ & $\begin{array}{l}119 \\
(78.3 \%)\end{array}$ \\
\hline Yes & $20(11.6 \%)$ & $\begin{array}{l}3 \\
(15.0 \%)\end{array}$ & $\begin{array}{l}17 \\
(85.0 \%)\end{array}$ & $\begin{array}{l}0.61 \\
(0.17- \\
2.21)\end{array}$ & $\begin{array}{l}1 \\
(5.0 \%)\end{array}$ & $\begin{array}{l}19 \\
(95.0 \%)\end{array}$ & $\begin{array}{l}0.39 \\
(0.05- \\
3.11)\end{array}$ & $\begin{array}{l}0 \\
(0.0 \%)\end{array}$ & $\begin{array}{l}20 \\
(100.0 \%)\end{array}$ & - & $\begin{array}{l}1 \\
(5.0 \%)\end{array}$ & $\begin{array}{l}19 \\
(95.0 \%)\end{array}$ \\
\hline
\end{tabular}

Length from

Onset (to

Interview)

\begin{tabular}{|c|c|c|c|c|c|c|c|c|c|c|c|c|}
\hline$\leq 3$ months & 92 (53.5\%) & $\begin{array}{l}25 \\
(27.2 \%)\end{array}$ & $\begin{array}{l}67 \\
(72.8 \%)\end{array}$ & 1 (Ref) & $\begin{array}{l}11 \\
(12.0 \%)\end{array}$ & $\begin{array}{l}81 \\
(88.0 \%)\end{array}$ & 1 (Ref) & $\begin{array}{l}16 \\
(17.4 \%)\end{array}$ & $\begin{array}{l}76 \\
(82.6 \%)\end{array}$ & 1 (Ref) & $\begin{array}{l}18 \\
(19.6 \%)\end{array}$ & $\begin{array}{l}74 \\
(80.4 \%)\end{array}$ \\
\hline$>3$ months & $80(46.5 \%)$ & $\begin{array}{l}12 \\
(15.0 \%)\end{array}$ & $\begin{array}{l}68 \\
(85.0 \%)\end{array}$ & $\begin{array}{l}0.47 \\
(0.22- \\
1.02)\end{array}$ & $\begin{array}{l}8 \\
(10.0 \%)\end{array}$ & $\begin{array}{l}72 \\
(90.0 \%)\end{array}$ & $\begin{array}{l}0.82 \\
(0.31- \\
2.15)\end{array}$ & $\begin{array}{l}10 \\
(12.5 \%)\end{array}$ & $\begin{array}{l}70 \\
(87.5 \%)\end{array}$ & $\begin{array}{l}0.68 \\
(0.29- \\
1.59)\end{array}$ & $\begin{array}{l}16 \\
(20.0 \%)\end{array}$ & $\begin{array}{l}64 \\
(80.0 \%)\end{array}$ \\
\hline
\end{tabular}

Long Covid

\begin{tabular}{|c|c|c|c|c|c|c|c|c|c|c|c|c|}
\hline No & $120(69.8 \%)$ & $\begin{array}{l}22 \\
(18.3 \%)\end{array}$ & $\begin{array}{l}98 \\
(81.7 \%)\end{array}$ & 1 (Ref) & $\begin{array}{l}10 \\
(8.3 \%)\end{array}$ & $\begin{array}{l}110 \\
(91.7 \%)\end{array}$ & 1 (Ref) & $\begin{array}{l}15 \\
(12.5 \%)\end{array}$ & $\begin{array}{l}105 \\
(87.5 \%)\end{array}$ & 1 (Ref) & $\begin{array}{l}24 \\
(20.0 \%)\end{array}$ & $\begin{array}{l}96 \\
(80.0 \%)\end{array}$ \\
\hline Yes & $52(30.2 \%)$ & $\begin{array}{l}15 \\
(28.8 \%)\end{array}$ & $\begin{array}{l}37 \\
(71.2 \%)\end{array}$ & $\begin{array}{l}1.81 \\
(0.85- \\
3.85)\end{array}$ & $\begin{array}{l}9 \\
(17.3 \%)\end{array}$ & $\begin{array}{l}43 \\
(82.7 \%)\end{array}$ & $\begin{array}{l}2.30 \\
(0.87- \\
6.06)\end{array}$ & $\begin{array}{l}11 \\
(21.2 \%)\end{array}$ & $\begin{array}{l}41 \\
\text { (78.8\%) }\end{array}$ & $\begin{array}{l}1.88 \\
(0.80- \\
4.43)\end{array}$ & $\begin{array}{l}10 \\
(19.2 \%)\end{array}$ & $\begin{array}{l}42 \\
(80.8 \%)\end{array}$ \\
\hline
\end{tabular}

Number of 


\begin{tabular}{|c|c|c|c|c|c|c|c|c|c|c|c|c|}
\hline No & $120(69.8 \%)$ & $\begin{array}{l}22 \\
(18.3 \%)\end{array}$ & $\begin{array}{l}98 \\
(81.7 \%)\end{array}$ & 1 (Ref) & $\begin{array}{l}10 \\
(8.3 \%)\end{array}$ & $\begin{array}{l}110 \\
(91.7 \%)\end{array}$ & 1 (Ref) & $\begin{array}{l}15 \\
(12.5 \%)\end{array}$ & $\begin{array}{l}105 \\
(87.5 \%)\end{array}$ & 1 (Ref) & $\begin{array}{l}24 \\
(20.0 \%)\end{array}$ & $\begin{array}{l}96 \\
(80.0 \%)\end{array}$ \\
\hline 1 Symptom & $41(23.8 \%)$ & $\begin{array}{l}11 \\
(26.8 \%)\end{array}$ & $\begin{array}{l}30 \\
(73.2 \%)\end{array}$ & $\begin{array}{l}1.63 \\
(0.71- \\
3.75)\end{array}$ & $\begin{array}{l}7 \\
(17.1 \%)\end{array}$ & $\begin{array}{l}34 \\
(82.9 \%)\end{array}$ & $\begin{array}{l}2.26 \\
(0.80- \\
6.40)\end{array}$ & $\begin{array}{l}9 \\
(22.0 \%)\end{array}$ & $\begin{array}{l}32 \\
(78.0 \%)\end{array}$ & $\begin{array}{l}1.97 \\
(0.79- \\
4.92)\end{array}$ & $\begin{array}{l}8 \\
(19.5 \%)\end{array}$ & $\begin{array}{l}33 \\
(80.5 \%)\end{array}$ \\
\hline > 1 Symptom & $11(6.4 \%)$ & $\begin{array}{l}4 \\
(36.4 \%)\end{array}$ & $\begin{array}{l}7 \\
(63.6 \%)\end{array}$ & $\begin{array}{l}2.54 \\
(0.68- \\
9.46)\end{array}$ & $\begin{array}{l}2 \\
(18.2 \%)\end{array}$ & $\begin{array}{l}9 \\
(81.8 \%)\end{array}$ & $\begin{array}{l}2.44 \\
(0.46- \\
12.89)\end{array}$ & $\begin{array}{l}2 \\
(18.2 \%)\end{array}$ & $\stackrel{9}{(81.8 \%)}$ & $\begin{array}{l}1.56 \\
(0.31- \\
7.90)\end{array}$ & $\begin{array}{l}2 \\
(18.2 \%)\end{array}$ & $\begin{array}{l}9 \\
(81.8 \%)\end{array}$ \\
\hline
\end{tabular}

Table 6. Results of Multivariable analysis of Quality of Life Domains and Gender, Age Group, Marital Status, Occupation and Having Long-Haul COVID 19

\begin{tabular}{|c|c|c|c|c|c|}
\hline \multirow[t]{2}{*}{ No } & Variables & $\begin{array}{l}\text { Physical } \\
\text { Domain }\end{array}$ & $\begin{array}{l}\text { Psychological } \\
\text { Domain }\end{array}$ & Social Domain & $\begin{array}{l}\text { Environmental } \\
\text { Domain }\end{array}$ \\
\hline & & AOR $(95 \% \mathrm{Cl})$ & AOR $(95 \% \mathrm{Cl})$ & AOR $(95 \% \mathrm{Cl})$ & $\operatorname{AOR}(95 \% \mathrm{Cl})$ \\
\hline 1 & Gender (Female/ Male) & $\begin{array}{l}1.50(0.66- \\
3.39)\end{array}$ & $1.70(0.55-5.22)$ & $\begin{array}{l}2.30(0.88- \\
6.05)\end{array}$ & $2.23(0.95-5.22)$ \\
\hline 2 & Age Group ( $\geq 40$ years old/ $18-39$ years old) & $\begin{array}{l}1.85(0.79- \\
4.35)\end{array}$ & $3.68(1.17-11.61)$ & $\begin{array}{l}1.26(0.45- \\
3.50)\end{array}$ & $1.14(0.46-2.80)$ \\
\hline 3 & $\begin{array}{l}\text { Marital Status (Divorced \& Single/ Married \& Living With } \\
\text { Partner) }\end{array}$ & $\begin{array}{l}1.55(0.68- \\
3.53)\end{array}$ & $0.80(0.24-2.63)$ & $\begin{array}{l}2.48(0.99- \\
6.18)\end{array}$ & $1.63(0.72-3.71)$ \\
\hline $4 a$ & Occupation (Private Sector / Civil Servant \& Police \& Army) & $\begin{array}{l}0.62(0.24- \\
1.56)\end{array}$ & $0.94(0.29-3.10)$ & $\begin{array}{l}1.28(0.41- \\
4.00)\end{array}$ & $0.98(0.38-2.56)$ \\
\hline $4 b$ & Occupation (Unemployed / Civil Servant \& Police \& Army) & $\begin{array}{l}0.91(0.29- \\
2.89)\end{array}$ & $0.55(0.11-2.77)$ & $\begin{array}{l}0.90(0.21- \\
3.96)\end{array}$ & $0.70(0.19-2.53)$ \\
\hline 5 & Long-Haul COVID 19 (Yes/ No) & $\begin{array}{l}1.93(0.88- \\
4.23)\end{array}$ & $2.62(0.96-7.14)$ & $\begin{array}{l}2.09(0.85- \\
5.12)\end{array}$ & $0.99(0.43-2.30)$ \\
\hline
\end{tabular}

